\title{
Cutaneous Melanoma pT3b TNM Finding v6 and v7
}

National Cancer Institute

\section{Source}

National Cancer Institute. Cutaneous Melanoma pT3b TNM Finding v6 and v7. NCI

Thesaurus. Code C48850.

Cutaneous melanoma 2.01 to $4 \mathrm{~mm}$ thick, with ulceration. (from AJCC 6th and 7th Eds.) 